\title{
HOW COLLECTIVISM AND FAMILY CONTROL INFLUENCE DEPRESSIVE SYMPTOMS IN ASIAN AMERICAN AND EUROPEAN AMERICAN COLLEGE STUDENTS
}

\author{
ASYA VE AVRUPA KÖKENLI AMERIKALI ÜNIVERSITE ÖĞRENCILERININ DEPRESIF \\ SEMTOMLARINI TOPLULUKÇULUK VE AILE KONTROLU NASIL ETKILER
}

DOI:10.17755/esosder.09354

\section{Ayşe AYÇIÇEĞİ DINN ${ }^{1}$ \\ Catherine L CALDWELL-HARRIS ${ }^{2}$}

\begin{abstract}
How the cultural values of individualism and collectivism influence depression in Asian heritage college students was investigated using questionnaire methodology. Results replicated the existing finding of greater report of high parental control and depressive symptoms among Asian American students compared to European American. Higher reports of depressive symptoms were linked to failures of personal achievement in both groups, but family control and vertical collectivism were associated with depressive symptoms only for Asian Americans (especially males). Values related to vertical collectivism were endorsed by Asian Americans twice as frequently as they were by European Americans. Because vertical collectivism emphasizes duty and subordinating of one's own goals to those of authority figures, it may be a risk factor for depression for Asian Americans, as they often must integrate family expectations of goal subordination while living in a society which values individual expression and following one's own path. Questionnaires additionally included exploratory questions to assess students' own views about what experiences can cause depression. Both groups cited failures of personal achievement as likely causes of depression, while only Asian Americans cited family control as likely to cause depression.
\end{abstract}

Keywords: University students, depression, individualism-collectivism, asian-european

\section{$\ddot{O} \mathbf{z}$}

Asya kültürel mirasına sahip üniversite öğrencilerindeki depresyona bireyselcilik ve toplulukçuluk kültürel değerlerinin nasıl etki ettiği anket yoluyla belirlenmeye çalışılmıştır. Sonuçlar, Avrupalı Amerikalılarla karşılaştırıldığında Asyalı Amerikan öğrenciler arasındaki yüksek ebeveyn kontrolü ve depresif semptomların daha fazla olduğu bulgusunu desteklemiştir. Depresif semptomların daha yüksek olması her iki grupta da kişisel başarısızlıklarla ilişkilidir fakat aile kontrolü ve dikey toplulukçuluk sadece Asyalı Amerikanlardaki (özellikle erkekler) depresif semptomlarla ilişkilidir. Dikey toplulukçulukla ilişkili değerler Asyalı Amerikanlar tarafından Avrupalı Amerikanlardakinden iki kat daha sıklıkla kabul edilmiştir. Dikey toplulukçuluk, görevi ve kişinin kendi hedeflerinin yerine otorite figürlerininkine itaatini vurguladığı için, Asyalı Amerikanlar sıklıkla ailenin hedef itaati beklentilerini ve herkesin kendi yolunu çizdiği, bireysel dişavurumun ön planda olduğu bir toplumda yaşamayı kaynaştırmaya çalışırken, bu durum onlarda depresyon için bir risk faktörü olabilir. Anketler öğrencilerin hangi deneyimlerin depresyona neden olabileceği üzerinde kendi görüşlerini değerlendirmeleri için açıklamalı soruları da içermektedir. Her iki grup da kişisel başarısızlıkları depresyonun bir nedeni olarak belirtirken; aile kontrolünü sadece Asyalı Amerikanlar depresyon nedeni olarak belirtmiştir. Asya ve Avrupa kökenli Amerikalı üniversite öğrencilerinin depresif semptomlarını toplulukçuluk ve aile kontrolü nasıl etkiler

Anahtar Kelimeler: Üniversite öğrencileri, depresyon, bireyselcilik-toplulukçuluk, Asya Avrupa

\footnotetext{
${ }^{1}$ Prof.Dr., İstanbul 29 May University Faculty of Arts and Humanities, Psychology Department, aaycicegidinn@29mayis.edu.tr

2 Prof.Dr., Boston University, Psychology Department, charris@bu.edu
} 


\section{INTRODUCTION}

Different cultures have developed different solutions to social living; these different solutions have advantages and disadvantages. Collectivist cultures, such as those in East Asia and Mediterranean countries, emphasize relational interdependence, the mode of relying on family and in-group which has been the default for much of human history (Kagitçibasi, 1997; Hui \& Villareal, 1989; Hsu, 1983; Triandis, 1995). An advantage of interdependence is being socially sensitive and able to benefit from a rich network of family, friends, and community, thus minimizing loneliness and the requirement to chart one's own path (Waterman, 1984). A disadvantage is that collectivist cultures historically emphasized obedience to parents and subordinating one's own goals to those of the in-group, thus curtailing the pursuit of individual happiness (Hsu, 1983; Triandis, 2000). Individualistic societies (such as those in North America and Europe) frequently have 24-hour convenience stores, banks, insurance, daycare, governmental infrastructure that reduce the necessity of relying on family and in-group, thus allowing individuals to pursue their own goals (Triandis, 2000). A disadvantage is the despair that results when dreams are not attained, and loneliness from lack of strong relationships and rootedness in a community (Tafarodi \& Smith, 2001).

Differences between individualist and collectivist value systems are not abstractions but play out in daily life in North America in cross-cultural interactions between Americans and immigrants from different cultural backgrounds, or between children and their immigrant parents (Kim, Wang, Orozco-Lapray, Shen, \& Murtuza, 2013; Ying, Lee, \& Tsai, 2007). The current paper focuses on Asian American young adults, many of whom have grown up in a household where at least some traditional Asian values are endorsed (Juang, Qin, \& Park, 2013). This is a group where the intersection of cultural values and well-being is especially visible.

The parenting practices of Asian and Asian heritage parents are often distinct from those of White Americans, and include high levels of control and expectation of superior academic achievement (Lee \& Liu, 2001). Parents may also emphasize obedience to authority (Juang et al, 2013), and may use forms of shaming as part of motivation, such as comparing their children to siblings and friends (Supple \& Cavanaugh, 2013). An outcome is what has been called the "achievement/adjustment paradox" (Qin, 2008).This paradox is that Asian American high school and college students excel academically, but exhibit more depression and anxiety than White peers (Kanazawa, White, \& Hampson, 2007; Okazaki, 1997; Kim et al, 2013). Noting the lack of definitive findings about factors influencing Asian Americans' mental health and well-being, Ying et al. (2007) have issued a pleafor more research on how specific parenting practices influence psychosocial development. The current paper responds to this plea by surveying Asian American and European American college students on depressive symptoms, individualismcollectivism values, and their experiences of personal achievements and parental control.

\section{Individualism-collectivism, well-being, and the family}

One proposal about variations in individualism and collectivism is that in collectivist cultures, agreeableness as a personality trait is high, and people receive more social support (Bettencourt \& Dorr, 1997). This is thought to contrast with individualistic societies, which emphasize competitiveness, resulting in pressure to achieve, reducing subjective well-being (Triandis, 2000; Verkuyten \& Lay, 1998). 
However, Suh (2007) disputed the image of collectivist cultures as supporting high personal well-being. He reported on considerable stress and unhappiness among East Asians, and suggested that the reason is because cultural norms in East Asia have developed over centuries to maximize social stability, at the cost of curtailing individual expression (see also Tseng, Lin, \& Yeh, 1995). Suh's proposals are consistent with the Confucian emphasis on duty (Hsu, 1983). Duty is a key aspect of what is called vertical collectivism. While horizontal collectivism involves sharing and an egalitarian outlook, vertical collectivism emphasizes subordination of one's own goals to those of authority figures (Triandis, Bontempo, Villareal, Asai, \& Lucca, 1988). Vertical collectivism can increase subjective well-being for persons who agree with their cultures' values, but can decrease well-being if the values are not shared (Triandis, 2000). The result of this is that living in an individualistic or collectivistic culture for well-being, or of possessing collectivist (sometimes called allocentric) vs. individualist (sometimes called idiocentric) personality traits, are thus not obvious (Diener \& Suh, 2000).

\section{Hypotheses}

Hypothesis 1. Asian American students will be more collectivist in their values than European American students, especially regarding familialism and vertical collectivism.

Hypothesis 2. Asian American students will report more depressive symptoms than European American students.

Hypothesis 3. Asian American students will report more parental control than European American students; however, groups will not differ in report of personal achievements (which we construe broadly to include not just academic and work achievements, but satisfaction with friends and romantic relationships; La Greca \& Harrison, 2005).

Hypothesis 4. Vertical collectivism and the experience of parental control will be associated with depressive symptoms among both European Americans and Asian Americans, while familialism will protect against depression among both groups.

\section{Exploratory question: young adults' views on the causes of depression}

Conceptions of the causes of depression are important because they predict response to treatment (Cornwall, Scott, Garland, \& Pollinger, 2005; Rippere, 1977). They also illuminate cultural values, and assessing them allows us to test the practical relevance of assumed crosscultural differences, such as differences in individualism and collectivism (Furnham \& Kuyken, 1991; Kuyken, Brewin, Power, \& Furnham, 1992). In a study of middle-aged British women and age-matched female Indian immigrants to Britain, Furnham and Malik (1994) found that achievement failures (e.g., "plans aren't going to work out") were cited by British women as plausible causes of depression, while loss of control was more salient as a cause of depression for Indian women. This result fits, at least very broadly, with more individualistic ideation for the British women (that is, "my individual plans") vs. less ego-centered ideation for the Indian women (i.e., fearing inference by external agents or forces).

As an exploratory measure, we developed survey questions about how much college students viewed personal achievement failures and family control to be plausible causes of depression. 
Hypothesis 5. Asian Americans will view parental control as a stronger cause of depression than will European Americans; however, the groups will be similar in their view of how personal achievement losses influence depression.

\section{METHODS}

\subsection{Participants}

Questionnaires were administered to 367 college students (246 females, 121 males) who resided in the northeastern region of the U.S. Students were recruited from several large introductory psychology classes and participated for course credit. Two recruitment flyers were used. One asked for Asian American students who identified their heritage as any part of East Asia ( $\mathrm{n}=136$ students, 87 females, 49 males). The other flyer read "all welcome." Students were categorized as European Americans $(n=231 ; 159$ females, 72 males) respondents if they selfidentified as white, Caucasian, or if they labeled their ethnicity as a European country/culture (e.g., Irish-American, Italian-American). Data from students who did not fit into these categories were not analyzed. The mean age for all groups was similar (range $=18.7-19.9$ years of age). Most students were in their first years of college (mean years of education $=13.0, S D=0.2$ ), and the mean years of education of the four groups was similar also (range $=13.0-13.1$ years of education). We did not categorize students according to East Asian culture and we did not ask about age of immigration to the U.S. or other aspects of acculturation. Our sample of Asian Americans is thus considerably more heterogeneous than some studies that have compared those born in America to early or late immigrants (e.g., Ying et al, 2007).

\subsection{Measures and Procedure}

Paper-and-pencil questionnaires were administered in a classroom setting to groups of students ranging in number from 10 to 25 .

Individualism, collectivism and depressive symptoms were measured using well-known scales from the research literature.We also prepared two sets of questions to explore how respondents felt about personal achievement and parental control, and two sets of questions about whether they felt achievement failure and parental control could potentially cause depression.

2.2.1. Cultural Orientation Scenarios: Sixteen short vignettes (scenarios), originally developed by Triandis, Chen and Chan (1998) to assess individualism and collectivism, were modified slightly to be maximally appropriate for our student groups (see Appendix A).Respondents chose which of four items is the best answer or completion to each sentence; each of the four items was designed to represent a value corresponding to HI, HC, VI, or VC. A respondent's total HI score is how many HI choices were selected out of 16 possible. An example of a vignette:

In an ideal society, national budgets will be determined so that:

- all people have adequate incomes to meet basic needs HC

- some people will be rewarded for making brilliant contributions VI

- there will be maximal stability, law and order VC

- people can follow their own path to a fulfilling life HI 
2.2.2. The Family Allocentrism Scale (Lay, Fairlie, Jackson, Ricci, Eisenberg, Sato, Teeaar,\& Melamud, 1998)measures familialism, a type of collectivism centered on commitment to family members. Example items include: "The opinions of my family are important to me" and "Once you are no longer living with your parents, they should no longer be involved in major life decisions" (reverse scored).Lay et al. (1998) reported that the 21-Likert items with 5-point scale measure a single underlying construct, as indicated by factor analysis; Cronbach's alpha was higher than 0.8 .

2.2.3. Beck Depression Inventory (Beck, Steer, \& Brown, 1996): For each of 21 items about a specific depressive symptom,respondents select the option that most accurately describes themselves.

The scenarios and the Family Allocentrism Scale were used in prior work (Aycicegi-Dinn \& Caldwell-Harris, 2011), with acceptable Cronbach alpha scores (0.8 or greater). Cronbach Alpha values and test-retest reliabilities for the exploratory questions are provided after each set of questions is explained below. Test-retest reliabilities were calculated using a small pilot sample $(n=28)$, with the two questionnaires administered with a three week break (see below for values).

Exploratory questions about respondents' experience of personal achievement $(n=6)$ and parental control $(n=6)$. Respondents used a 5-point Likert rating scale for 12 items such as "I am able to achieve my desired goals" and "My parents frequently criticize me or my lifestyle" (all items are in Appendix B). Questions were adapted from those used by Kim et al. (2013). Questions were evaluated and selected by a team of undergraduate research assistants which included Asian American students. The team selected items based on their relevance to the lives of Asian American college students and college students in general. Cronbach alpha values for the questions related to personal achievement and parental control were 0.75 and 0.82 , respectively. Test-retest reliabilities after a three week interval $(n=28$ respondents $)$ were 0.72 and 0.82 , respectively.

2.2.4. Exploratory questions on causes of depression: These were written to investigate respondents evaluation of how strongly personal achievement failures and excessiveparental control cause depression. Respondents rated items on a scale ranging from (1) "Is not at all a strong cause of depression" to (5) "Is a very strong cause of depression."Cronbach alpha values for the questions related to personal achievement and parental control were 0.74 . and 0.81 , respectively. Test-retest reliabilities were 0.72 and 0.92 .

\subsection{Data analysis plan}

Our design had two between-subject variables, cultural group and gender, and a variety of dependent variables. We conducted 2 X 2 ANOVAs, with factors cultural group and gender, on each of the dependent measures. The specific analyses were as follows. We analyzed the four individualism-collectivism measures of the cultural orientation scenarios using separate $2 \times 2$ ANOVAs, with factors cultural group and gender (results in Figure 1). A cultural group X gender ANOVA was also conducted on Beck Depression Inventory (BDI) Scores (results in Figure 2). For exploratory purposes, scales were created out of the family control questions and the personal achievement questions. These were again analyzed using 2 X 2 ANOVAs (cultural group X gender; results described in the text). A final set of 2 X 2 ANOVAs (with cultural group and gender as independent factors) were conducted on dependent variables corresponding to 
respondents' ratings about plausible causes of depression (results described in Table 4). Finally, a different type of analysis was multiple regression conducted on BDI scores, using as predictors scale values for personal achievement, family control, vertical collectivism, familialism and gender (see results in Table 3).

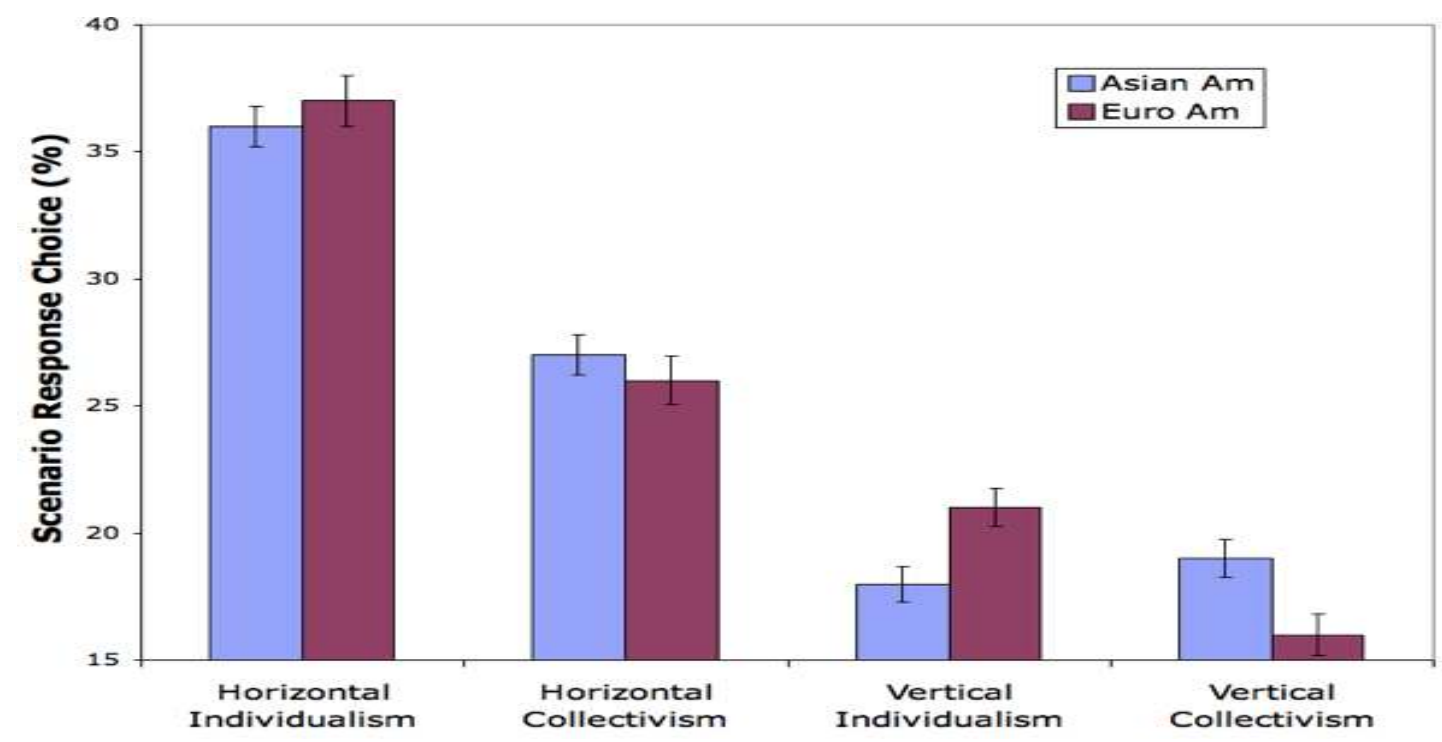

Figure 1: Individualism and Collectivism Measures. Percentages reflect the percent of scenarios for which participants endorsed each of the 4 response options.

\section{RESULTS}

\section{Group differences in individualism-collectivism and depressive symptoms}

Figure 1 shows how often the Asian and European Americans selected the HI, HC, VI, and $\mathrm{VC}$ responses to the scenarios. No main effects for gender were obtained. The cultural groups were overall quite similar to each other as is apparent by visually inspecting Figure 1. It is also apparent that horizontal response choices were the most common type of choice, consistent with the broad emphasis on egalitarian relationships common among college students in North America (Triandis et al, 1988). Groups were also highly similar to each other in their preference for horizontal responses, as determined lack of statistical significance of cultural group variable $(p s>.2)$. For the two vertical measures, main effects of cultural group were obtained, with European Americans endorsing more vertical individualism than Asian Americans, $F(1,207)=10.2, p<.01$, eta2 $=.05$; and with Asian Americans endorsing more vertical collectivism than European Americans, $F(1,207)=11.9, p<.001$, eta2=.05. Although Asian Americans $(M=74.0)$ did have slightly higher scores on the familialism measure than did European Americans $(M=72.0)$ this small difference was not statistically significant, $F(1,207)=2.5, p<.1)$.

An ANOVA conducted on report of depressive symptoms revealed a main effect for group, with Asian Americans reporting more symptoms than European Americans, $F(1,207)=4.9$, $p<.05$, eta2 $=.02$. There was also a gender $\mathrm{X}$ group interaction, $F(1,207)=6.2, p<.05$, eta2 $=.03$. The interaction occurred because among European Americans, females endorsed more depressive 
symptoms than males, which is the most frequently observed result for gender comparisons (Ying, Lee, \& Tsai, 2007; Ying \& Han, 2007).In contrast, Asian Americanmales reported more depressive symptoms than Asian American females (see Figure 2), a novel finding for Asian American college students in North America.

To interpret the group differences obtained on depressive symptoms, it is worth reviewing how the extent of symptoms endorsed by our respondents corresponds to what the designers of the Beck Depression Inventory regarded to be clinically significant depressive symptoms (Beck et al, 1996). Symptom report was high enough to suggest clinical depression for $8 \%$ of Asian Americans and 4\% of European Americans. Scores indicated borderline clinical depression for $2 \%$ of Asian Americans and 3\% of European Americans. A mild mood disturbance is suggested by the symptom endorsements of 25\% of Asian Americans and 13\% of European Americans.

\section{Exploratory questions: family control and personal achievement}

Table 1 shows the average correlations between the family control questions and Beck Depression Inventory scores (see top panel of Table 1). Note that significant correlations were mostly confined to the Asian Americans. For Asian Americans, depressive symptoms correlated with parents failing to give sufficient freedom, exerting too much control, criticizing lifestyle, and comparing one negatively to his/her friends. For European Americans, only one question correlated with depressive symptoms, parents criticizing the respondent's lifestyle.

The bottom panel of Table 1 shows the six personal achievement items. Asian and European Americans were quite similar. Both groups had similarly medium-sized correlations between lack of satisfaction with personal achievement and scores on the Beck Depression Inventory. For European Americans, all six items correlated with depressive symptoms, and for Asian Americans, five items correlated, with the non-correlating item being "I have sufficient money or other resources to meet my goals," an item that was only weakly correlated with depressive symptoms for European Americans. 


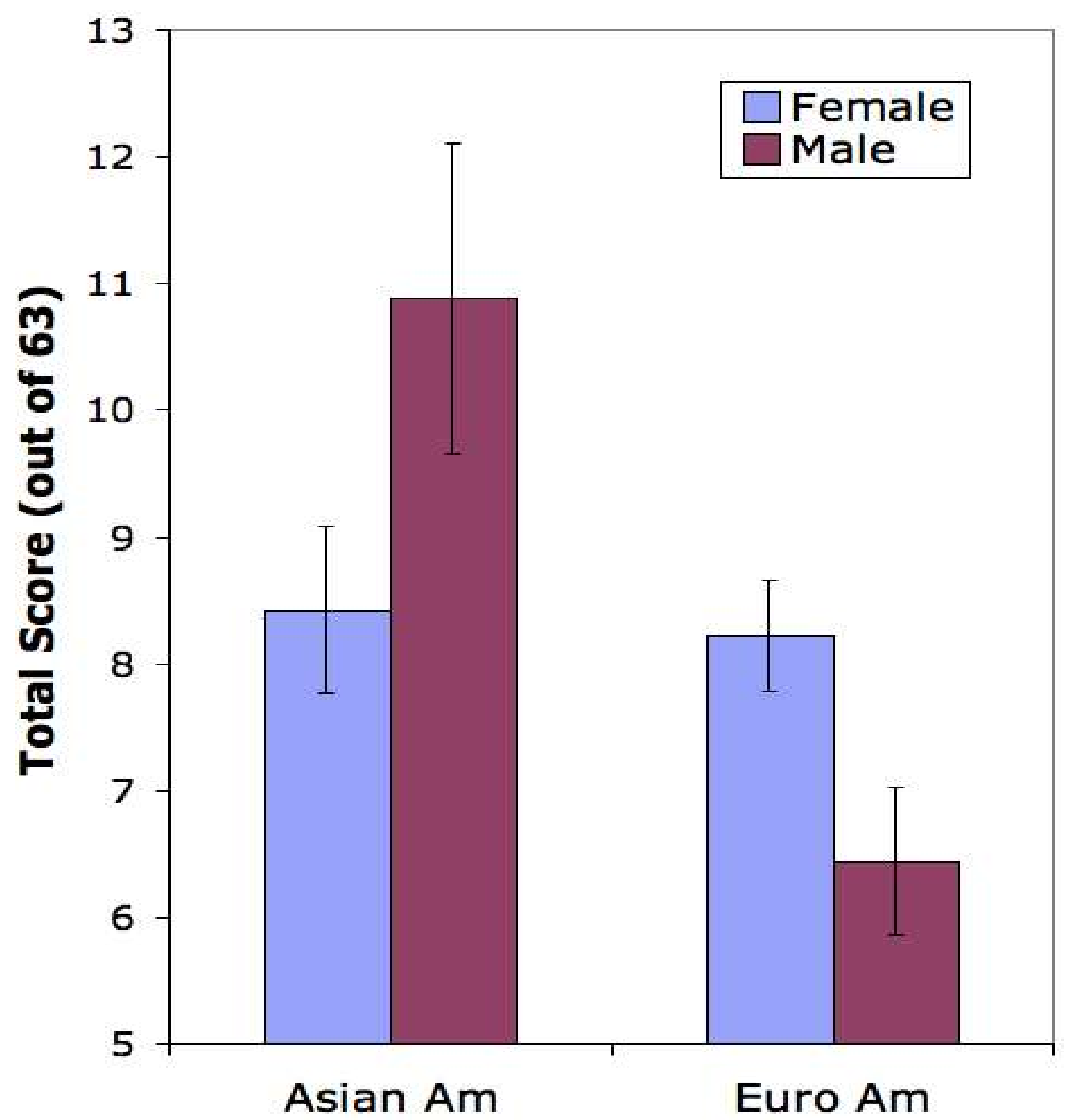

Figure 2: Group differences in depressive symptoms. Left-hand panel are total scores for the Beck Depression Inventory, out of 63 possible points. Scores of 1-10 represent normal variations in mood; 11-16 indicates a mild mood disturbance; 17-20 can be considered borderline clinical depression. 
Table 1 Correlations between depressive symptoms and report of personal achievement and family control

\begin{tabular}{|c|c|c|}
\hline Items & $\begin{array}{l}\text { European } \\
\text { Americans }\end{array}$ & Asian Americans \\
\hline \multicolumn{3}{|l|}{ Family Control Sub-scale } \\
\hline \multicolumn{3}{|l|}{$\begin{array}{l}\text { My family disapproves of my } \\
\text { friends }\end{array}$} \\
\hline $\begin{array}{l}\text { My parents exert too much control } \\
\text { over my life }\end{array}$ & & $.19 *$ \\
\hline $\begin{array}{l}\text { My parents compare me negatively } \\
\text { to my friends }\end{array}$ & & $.24 * *$ \\
\hline $\begin{array}{l}\text { My parents frequently criticize me } \\
\text { or my life style }\end{array}$ & $.34 * *$ & $.27 * *$ \\
\hline $\begin{array}{l}\text { My parents don't give me enough } \\
\text { freedom }\end{array}$ & & $.26 * *$ \\
\hline \multicolumn{3}{|l|}{$\begin{array}{l}\text { My parents disapprove of my } \\
\text { girlfriend/boyfriend }\end{array}$} \\
\hline \multicolumn{3}{|l|}{ Personal Achievement Sub-scale } \\
\hline I'm satisfied with my appearance & $-.32 * *$ & $-.47 * *$ \\
\hline I'm able to achieve my desired goals & $-.49 * *$ & $-.46 * *$ \\
\hline $\begin{array}{l}\text { I have sufficient money or other } \\
\text { resources to meet my goals }\end{array}$ & $-.22 *$ & \\
\hline $\begin{array}{l}\text { I have sufficient opportunities to } \\
\text { enjoy myself }\end{array}$ & $-.21 *$ & $-.19 *$ \\
\hline $\begin{array}{l}\text { I'm satisfied with my performance } \\
\text { at school/job }\end{array}$ & $-.42 * *$ & $-.53 * *$ \\
\hline I'm happy with my school/job & $-.51 * *$ & $-.55 * *$ \\
\hline
\end{tabular}

Table note. Blank cells had nonsignificant correlations. $* p<.05 * * p<.01$

To further explore how cultural groups differed in their responses to these questions, the family control items were treated as a scale by averaging responses across the six items for each respondent. A 2 X 2 ANOVA (culture $X$ gender) revealed no effect of gender, but a main effect of group, $F(1,207)=9.4, p<.01$, eta $2=.04$, with Asian Americans $(M=13.4)$ reporting a greater degree of parental control than did European Americans $(M=11.5)$. The numerically highest report of parental control occurred for Asian American males $(M=14.4)$ and the lowest was for European American males $(M=11.2)$, although the gender $\mathrm{X}$ culture interaction was not statistically significant, $p>0.1$.

When the personal achievement items were treated as a separate scale, no gender or cultural main effects were obtained, confirming the impression from the correlations just 
described that Asian and European Americans responded to the personal achievement items in similar ways.

\section{Correlations between variables and multiple regression}

Associations between individualism, collectivism, depressive symptoms, and experiences of personal achievement and family control were investigated by obtaining correlation coefficients. These correlations appear in Table 2. Beck Depression Inventory (BDI) scores were strongly correlated with respondents' reports of failures of personal achievement (negative r-values occurred because the personal achievement items are stated in the positive direction). Family control was weakly correlated with BDI scores for Asian Americans. Note that for Asian Americans, vertical collectivism was as strongly correlated with depressive symptoms as was the experience of family control (see Table 2). Family control and vertical collectivism were also strongly correlated for Asian Americans $(r=0.50, p<.01)$.

Multiple regression to predict depressive symptoms was conducted, separately for the two groups, using the variables in Table 2 and gender. The summary of the multiple regression appears in Table 3. For European Americans, personal achievement was the only variable that accounted for unique variance in Beck Depression Inventory scores. For Asian Americans, personal achievement reports accounted for a third of the variance in depressive symptoms, with vertical collectivism accounting for an additional $5 \%$ of variance. 
Table 2 Correlations with Beck Depression Inventory Scores

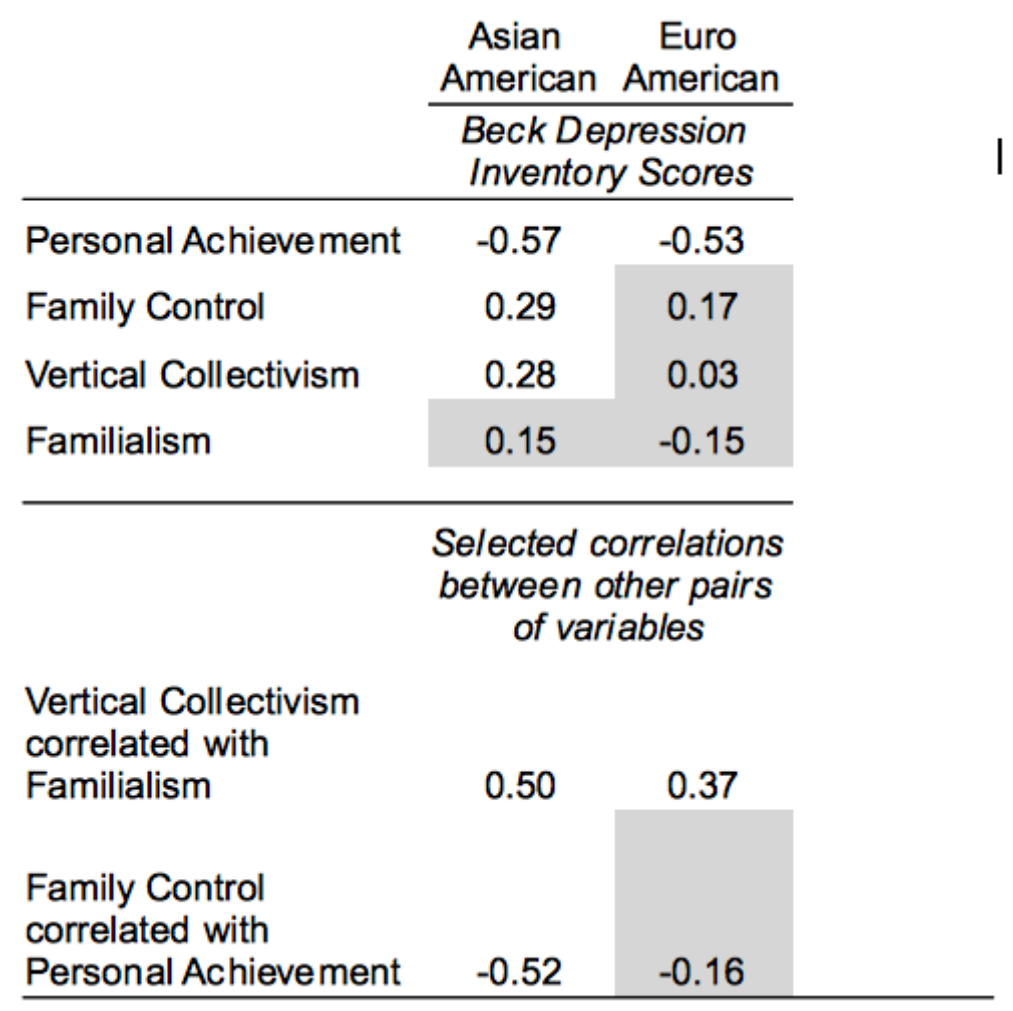

Table note. Correlations in shaded areas were not statistically significant; other correlations were significant at $\mathrm{p}<.01$ or stronger. 
Table 3 Multiple Regression Analysis for Predictors of Beck Depression Inventory Scores

\begin{tabular}{|c|c|c|c|c|c|}
\hline \multicolumn{6}{|c|}{ European Americans } \\
\hline Predictors & $\mathrm{R}^{2}$ & Change in $\mathrm{R}^{2}$ & $\mathrm{~B}$ & $\begin{array}{c}\text { Standardized } \\
\text { Beta }\end{array}$ & $\mathrm{T}$ \\
\hline $\begin{array}{l}\text { Experiences of } \\
\text { personal } \\
\text { achievement }\end{array}$ & 29 & -- & -.74 & -.54 & $6.49 * * *$ \\
\hline \multicolumn{6}{|l|}{ Asian Americans } \\
\hline Predictors & $\mathrm{R}^{2}$ & Change in $\mathrm{R}^{2}$ & B & $\begin{array}{r}\text { Standardized } \\
\text { Beta }\end{array}$ & $\mathrm{T}$ \\
\hline $\begin{array}{l}\text { Experiences of } \\
\text { personal } \\
\text { achievement }\end{array}$ & 33 & -- & -.88 & -.52 & $6.82 * * *$ \\
\hline $\begin{array}{l}\text { Vertical } \\
\text { Collectivism }\end{array}$ & 38 & .05 & 18.5 & .21 & $2.72 * *$ \\
\hline
\end{tabular}

Table notes. $* * * p<.001, * * p<.01, * p<.05$

Since vertical collectivism revealed an association with depressive symptoms for Asian Americans but not European Americans, it is worth noting that vertical collectivism values were rare in both groups. On average, Asian Americans selected VC response options for three of the 16 scenarios. European Americans made fewer than two VC responses, on average. Fifteen percent of Asian Americans selected the VC response option for approximately a third of their choices; the remaining $85 \%$ of Asian Americans made fewer than $30 \% \mathrm{VC}$ choices. But VC choices were even rarer among European Americans. Only seven percent of European Americans made as many as $1 / 3$ of their response options be $\mathrm{VC}$ responses.

\section{Group differences in lay theories of the causes of depression}

Separate 2 X 2 ANOVAs (with cultural group and gender as factors) were conducted using average scores on respondents' ratings about experiences that could be a cause of depression.

Causes related to family control revealed a strong main effect of cultural group, $F(1,207)=18.3, p<.001$, eta2 $=.08$, with Asian Americans $(M=19.9)$ citing family control as a stronger cause of depression than did European Americans $(M=16.9)$. There was also a gender X group interaction, $F(1,207)=4.4, p<.05$, eta $=.02$. This interaction occurred because European American males reported family control to be a quite weak weak (or unlikely) cause of depression (see shaded cell in Family control row of Table 4), compared to the other three three categories of participants. 
The ANOVA conducted on personal achievement as a cause of depression revealed a main effect of gender, $F(1,207)=5.8, p<.05$, eta2 $=.03$. Asian and European American females $(M=22.9)$ more likely than males from both groups (i.e., Asian American and European American) $(M=21.1)$ to cite personal achievement failures as a cause of depression (see female means, which are shaded cells in the Personal achievement row of Table 4).

Table 4. Experiences judged to be a likely cause of depression

\begin{tabular}{l|cc|cc|c|}
\hline \multicolumn{1}{c|}{} & \multicolumn{2}{|c|}{ Males } & \multicolumn{2}{c|}{ Females } \\
\cline { 2 - 5 } & Asian & Euro & Asian & Euro \\
\hline Family control & American & American & American & American \\
\hline Personal achievement & 20 & 15.3 & 19.8 & 18.2 \\
\cline { 2 - 5 } & 21.5 & 20.9 & 23.2 & 22.3 \\
\hline
\end{tabular}

\section{DISCUSSION}

Hypothesis 1.This hypothesis was partially supported. Asian Americans made more vertical collectivism choices on average on the Cultural Orientation Scenarios than did European Americans. However, this was a small effect, with only about $15 \%$ of Asian Americans selecting the vertical collectivism response options for a third of the scenarios, compared to $7 \%$ of European Americans. Although a small effect, it is potentially important since endorsing vertical collectivism values was more common among Asian Americans who report more depressive symptoms, as discussed below.

The two groups did not differ significantly in their endorsement of familialism. Although it is widely understood that close family relations are a key aspect of East Asian societies (e.g., Hsu, 1983), there is prior cross-national research showing that Americans were not lower in familialism than Japanese and Chinese (Oyserman et al, 2002). Our results confirm this finding. We conclude that familialism is not the type of collectivism that differentiates Asian American and European American college students. Instead, the system of values which does distinguish these groups is vertical collectivism, which includes respect for hierarchy and willingness to subordinate one's own goals to those of authority figures (with the caveat that only a minority of Asian American students show elevated vertical collectivism responding).

Hypothesis 2. This hypothesis was confirmed. Asian American students reported more depressive symptoms than did European American students, consistent with prior work (e.g., Greenberger \&Chen,1996). Although the majority of all respondents had Beck Depression Inventory scores consistent with normal mood, twice as many Asians Americans as European Americans had scores indicating a mild mood disturbance (25\% vs. $13 \%$, respectively) and twice as many has scores suggesting clinical depression ( $8 \%$ vs. $4 \%$ respectively). This extends prior research showing more depressive symptoms for Asian Americans (Okazaki, 1997). It is consistent with prior work with members of a primarily collectivist culture, the study of Japanese Americans in Hawaii (Kanazawa, White \& Hampson, 2007), and the greater dysphoria obtained for Malaysian sojourners in Britain (Tafarodi \& Smith, 2001).

Our unexpected gender finding was that Asian American males reported more depressive symptoms than Asian American females, the reverse of typical gender findings (see Figure 2). 
As discussed below, we propose that this is because Asian American males experience high levels of family control in a society where this is not the norm for males.

Hypothesis 3.This hypothesis was confirmed. Asian Americans reported more parental control than European Americans, as reported by Juang et al. (2013). Also, as expected, the two groups were highly similar in their report of personal achievements (e.g., satisfied with appearance; able to achieve goals; school/job performance). In addition, ratings on five of the six personal achievement questions correlated with depressive symptoms similarly for the two groups.

Hypothesis 4. This hypothesis was partially supported in ways that make sense given the existing research literature. Among Asian Americans but not European Americans, more endorsement of vertical collectivism was associated with higher report of depressive symptoms; vertical collectivism scores account for unique variance in depressive symptoms. Similarly, parental control was weakly associated with Beck Depression Inventory scores for Asian but not European Americans (see Table 2).

Contrary to our hypothesis, familialism was not correlated with depressive symptoms. This contrasts with a prior finding among Turkish university students where higher familialism was associated with lower report of depressive symptoms, using the same measures as the current study (Authors, 2013). However, the Turks resembled the Asian Americans by showing an association between vertical collectivism and depressive symptoms. The current study with Asian Americans thus replicates the vertical collectivism finding in the Turkish study, but not the finding of familialism protecting from depression. As many cross-cultural researchers have noted, how factors protect or predispose towards depression varies widely across cultural groups (Ying et al, 2007).

Hypothesis 5.This hypothesis was supported, as Asian Americans endorsed excessive family control as a likely cause of depression, at higher rates than did European Americans (see Figure 5). In contrast, both groups endorsed achievement failures (both achievements in the personal domain and social achievements) as likely to cause depression. This suggests that thesocial emphasis on achievements in American culture is internalized by young adults such that achievement failures are viewed as likely causes of depression. In both cultural groups, females endorsed failures of personal achievement as stronger causes of depression than did males. This may reflect females' greater tendency to ruminate about their life problems (see discussion in Ying et al, 2007).

An intriguing gender interaction occurred in an unexpected distinction between Asian American and European American males. Asian American males had the strongest endorsements of parental control as a cause of depression and European American males the weakest. This was also the pattern obtained with report of how much family control was experienced. We view the relatively high rate of depressive symptoms among Asian American males to be caused, in part, by their experience of high rates of parental control. Our findings of elevated depressive symptoms among young males can be compared to those of Supple and Cavanaugh (2013). Those authors reported that culture-based conflicts with parents were associated with depressive symptoms in middle-school aged boys (but not girls). We speculate that the negative aspects of parental control may gain force while residing in a country where males of the dominant ethnic group generally experience somewhat lower levels of parental control. This proposal could be explicitly tested in future research. 


\section{CONCLUSIONS}

A key question was how individualist-collectivist values relate to depressive symptoms, and the role of the family. Why didn't familialism, which measures closeness and support, protect from depression? In this sample, familialism was correlated with vertical collectivism, which was correlated with reports of parental control and depressive symptoms. Thus if family support could have offered protection against depressive symptoms, this was washed out by its association with vertical collectivism.

Is vertical collectivism always associated with depressive symptoms? No, since we found this relationship only held for the Asian American group in our sample. However, vertical collectivism may have been too low in the European American groupto be significantly correlated with depressive symptoms. Triandis (2000) noted that vertical collectivism can enhance subjective well-being for individuals who agree with the values of authority figures. We thus suggest that endorsing vertical collectivist values is a stressor for the students we studied, because of the need to subordinate individual goals to those of in-group and authority figures, and the conflicts between this need and the achievement aspirations which are prevalent among college students in the U.S. A question for a future longitudinal study is whether vertical collectivism ceases to be associated with depressive symptoms among Asian American males as they increase in age and status.

Higher reports of depressive symptoms by females compared to males were restricted to our European American sample and were not found for Asian Americans. The pattern obtained in the current study is consistent with "social sensitivity theory." Valuing connections and interdependence with others is a risk factor for depression in cases when social relations are ruptured and intimacy lost. For groups high in collectivism, both genders share these values and thus gender differences were not correlated with depression or report of depressive symptoms. However, our data still present some puzzles. European American females reported more depressive symptoms than European American males (see Figure 2), but did not differ from them in collectivism and familialism. There are two possible ways to explain this. The scales used to measure collectivism and familialism may not be sensitive to the precise ways that European American females experience needs for intimacy and social bonds. This is not surprising, since the collectivism scales emphasize connection to family (the familialism scale) and subordination of goals to family members and in-group authority figures (vertical collectivism scale). These are not strong American values. European American females' greater report of depressive symptoms may mainly revolve around romantic and intimacy losses. However, both Asian American and European American females were more likely than males to say that failures to achieve social goals were causes of depression, and also more likely than males to report that personal achievement failures would be causes of depression (see Table 4). It thus remains possible that "social status theory" (Belle, 1982) is the best explanation for European American females' greater depression relative to European American males. The implication is that European American females care more about the diminished opportunities and greater stress accompanying their lower status than do Asian American females.

Asian American males reported more depressive symptoms than Asian American females. This plausibly reflects not greater social sensitivity but the dissonance between American achievement goals and the burden of criticism/control by family, and the need to fulfill family 
obligations. Future work can examine more explicitly how these are experienced by Asian American males and females.

\section{REFERENCES}

Aycicegi-Dinn A, Caldwell-Harris CL. Individualism-collectivism among Americans, Turks and Turkish immigrants to the U.S. International Journal of Intercultural Relations, 35: 916,2011

Beck AT, Steer RA, Brown GK. Beck Depression Inventory manual (2nd ed). San Antonio, TX: The Psychological Corp, 1996

BelleD. Lives in stress: Women and depression. Beverly Hills, CA: Sage Publications, 1982

Bettencourt BA, Dorr N. Collective self-esteem as a mediator of the relationship between allocentrism and subjective well-being. Personality and Social Psychology Bulletin, 23: 963-9, 1997

Cornwall PL, Scott J, Garland A, Pollinger R. Beliefs about depression in patients and their partners. Behavioural and Cognitive Psychotherapy, 33:131-138,2005

Diener E, Suh EM. Culture and subjective well-being. Cambridge, MIT Press, 2000

Furnham A, Kuyken W. Lay theories of depression. Journal of Social Behavior and Personality, 6: 329-342, 1991

Furnham A, Malik R. Cross-cultural beliefs about "depression". International Journal of Social Psychiatry, 40: 106-123, 1994

Greenberger E, Chen C. Perceived family relationships and depressed mood in early and late adolescence: A comparison of European and Asian Americans. Developmental Psychology, 32: 707-716, 1996

Hsu FLK. Rugged individualism reconsidered. Knoxville, University of Tennessee Press, 1983

Hui CH, Villareal MJ. Individualism-collectivism and psychological needs: Their relationships in two cultures. Journal of Cross-Cultural Psychology, 20: 310-323, 1989

Juang LP, Qin DB, Park IJK. Deconstructing the myth of the "Tiger Mother": An introduction to the special issue on tiger parenting, Asian-heritage families, and child/adolescent wellbeing. Asian American Journal of Psychology, 4: 1-6, 2013

Kagitcibasi, C. Individualism and collectivism. In Berry JW, Segall MH, Kagitcibasi C (Eds). Handbook of cross-cultural psychology, Volume 3: Social behavior and applications. Needham Heights, Allyn Bacon, 1997

Kanazawa A, White PM, Hampson SE. Ethnic variation in depressive symptoms in a community sample in Hawaii.Cultural Diversity and Ethnic Minority Psychology, 13: 35-44, 2007

Kim SY, Wang Y, Orozco-Lapray D, Shen Y, Murtuza M. Does "Tiger Parenting" exist? Parenting profiles of Chinese Americans and adolescent developmental outcomes. Asian American Journal of Psychology, 4: 7-18, 2013

Kuyken W, Brewin, CR, Power MJ, Furnham A. Causal beliefs about depression in depressed patients, clinical psychologists and lay persons. British Journal of Medical Psychology, 65: 257-268, 1992

La Greca AM, Harrison HM. Adolescent peer relations, friendships, and romantic relationships: do they predict social anxiety and depression? Journal of Clinical Child and Adolescent Psychology, 34: 49-61, 2005 
Lay C, Fairlie P, Jackson S, Ricci T, Eisenberg J, Sato T, Teeaar A, Melamud A. Domainspecific allocentrism-idiocentrism: A measure of family connectedness. Journal of CrossCultural Psychology, 29, 434-460, 1998

Lee RM, Liu H. Coping with intergenerational family conflict: Comparison of Asian American, Hispanic, and European American college students. Journal of Counseling Psychology, 48: 410-419, 2001

Okazaki S. Sources of ethnic differences between Asian American and White American college students on measures of depression and social anxiety. Journal of Abnormal Psychology, 106: 52-60, 1997

Oyserman D, Coon HM, Kemmelmier M. Rethinking individualism and collectivism: Evaluation of theoretical assumptions and meta-analyses. Psychological Bulletin, 128: 3-72, 2002

Qin DB. Doing well vs. feeling well: Understanding family dynamics and the psychological adjustment of Chinese immigrant adolescents. Journal of Youth and Adolescence, 37: 2235,2008

Rippere V. Commonsense beliefs about depression and anti-depressive behaviour. A study of social consensus. Behaviour Research and Therapy, 15: 465-473, 1977

Suh EM. Downsides of an overly context-sensitive self: implications from the culture and subjective well-being research. Journal of Personality, 75: 1321-1343, 2007

Supple A, Cavanaugh AM. Tiger mothering and among American parent-adolescent relationships. Asian American Journal of Psychology, 4: 41-49, 2013

Tafarodi RW, Smith AJ. Individualism-collectivism and depressive sensitivity to life events: the case of Malaysian sojourners. International Journal of Intercultural Relations, 25: 73-88, 2001

Triandis $\mathrm{CH}$, Bontempo B, Villareal JM, Asai M, Lucca N. Individualism and collectivism: Cross-cultural perspectives on self-ingrouprelationships. Journal of Personality and Social Psychology, 54: 323-338, 1988

Triandis HC, Chen XP, Chan DKS. Scenarios for the measurement of collectivism and individualism. Journal of Cross-Cultural Psychology, 20: 275-289, 1998

Triandis HC. Individualism and collectivism. Boulder, CO: Westview Press, 1995

Triandis HC. Cultural syndromes and subjective well-being. In Diener E, Suh EM (Eds). Culture and subjective well-being. Cambridge, MA: MIT Press, 2000

Tseng WS, Lin TY, Yeh EK. Chinese societies and mental health. In Lin TY, Tseng TS, Yeh EK (Eds).Chinese societies and mental health. Hong Kong, Oxford University Press, 1995, pp 3-18

Verkuyten M, Lay C. Ethnic minority identity and psychological well-being: The mediating role of collective self-esteem. Journal of Applied Social Psychology, 28: 1969-1986, 1998

Waterman AS. The psychology of individualism. New York, Praeger, 1984

Ying Y, Han M. Familism and mental health: Variation between Asian American children of refugees and immigrants. International Journal of Applied Psychoanalytic Studies, 4: 333-348, 2007

Ying YW, Lee PA, Tsai JL. Predictors of depressive symptoms in Chinese American college students: parent and peer attachment, college challenges and sense of coherence. American Journal of Orthopsychiatry, 77: 316-323, 2007. 


\section{APPENDIX A. INDIVIDUALISM-COLLECTIVISM SCENARIOS}

Scoring and administration notes. Produces 4 scales which are percents, ranging from 0 to $100 \%$. Scoring category is provided after each response option (e.g., HI=Horizontal Individualism; $\mathrm{VC}=$ Vertical Collectivism, etc.). The instructions here specify to make a first and a second choice, but some researchers may prefer to ask respondents to make a single choice. Scores can be based on just the first choice, in which case each of VI, VC, HI and HC will be the number of VI, VC, HI, or HC choices made divided by the total number of scenarios $(16$, or fewer if a given participant omitted an answer to one or more scenarios. To use both the first and second choice, as done in the current study, give the first choice two points, the second choice 1 point, and divide the total obtained by each sub-scale by 48 .

Please read each of the following scenarios. Imagine yourself in these situations. Place a 1 next to the item that would be your first choice, and a 2 for the item that would be your second choice.

1. You and your friends decided spontaneously to go out to dinner at a restaurant. What do you think is the best way to handle the bill?

_ Split it equally HC

- Those who earn more may pay slightly more if they want to be generous VI

_ The group leader (or whoever is most senior) pays the bill or decides how to spilt it

- $\mathrm{VC}$

_ Each person pays for approximately what their meal cost HI

2. You are buying a piece of art for your office. Which one factor is most important in deciding whether to buy it?

_ It is a good investment VI

- Your coworkers will like it HC

_ You just like it HI

- Your supervisor will approve of it. VC

3. Suppose you had to use one word to describe yourself. Which one would you use?

_ Unique HI

- Competitive VI

- Cooperative HC

_ Respectful VC4. Happiness is attained by

_ gaining respect and admiration from others $\mathrm{VC}$

_ having meaningful friendships HC

_ pursuing your own goals HI

_ winning in competitions VI

5. Imagine you are selecting a band for a fund-raising event given by your organization. Which are the most important factors in making your decision?

- Picking the band I think is the best HI

- My co-workers will be in general agreement that the band is good. HC

- The administration of my organization will approve of the band VC

- The band will help generate the most money. VI

6. Which one of these four self-help books are you most likely to read?

_ How to have high-quality, enduring friendships HC

_ How to succeed in business VI 
_ How to enjoy yourself inexpensively HI

- How to manage your time so that you can meet all your obligations to others. VC

7. Which would you most like to be recognized for in your workplace?

_ loyalty to the corporation $\mathrm{VC}$

_ being the expert. VI

_ being a good team player. HC

- being innovative HI

8. When you buy clothing for the annual office party, you would be most satisfied if your outfit

_ expresses your own unique style HI

_ is similar to the type of clothing chosen by your coworkers $\mathrm{HC}$

- will make you look good to your supervisors VC

- is so elegant that it will dazzle everyone VI

9. In an ideal society, national budgets will be determined so that

_ all people have adequate incomes to meet basic needs HC

_ some people will be rewarded for making brilliant contributions VI

- there will be maximal stability, law and order VC

_ people can follow their own path to a fulfilling life HI

10. When I reflect on what makes me the person I am, I think about:

_ The values my parents (and/or teachers) have instilled in me VC

- How I have learned and grown from exposure to friends and peers HC

- What I have achieved in the past, and what I expect to achieve in the future VI

- talk about what makes me unique HI

11.For designing the prototype for a new product, you and your 4 co-workers have been awarded a bonus of $\$ 500$. You and another person did $75 \%$ of the work to develop the prototype. How should the $\$ 500$ be distributed among the 5 of you?

_ Split it equally among the 5 co-workers HC

- The other person and I get $75 \%$ of the money and the rest goes to the

_ other 3 co-workers. VI

- The group leader decides how to split the money $\mathrm{VC}$

- Use all (or most) of the money to help the whole group start on a new project. HI

12. When voting for candidates in elections (e.g., school, city), you will vote for:

_ The one whose views are most similar to those of me and my peers HC

- The one whose personality and policies appeal to me the most HI

- The one whose policies will reward me personally VI

- The one whose policies will be most rewarding to my organization (or my group)VC

13. On your last visit to your parents' house, you noticed that it is becoming increasingly difficult for them to manage on their own. How would you approach this situation?

_ I would offer to have them come live with me (and my family). HC

_ I would start looking for retirement homes or assisted living communities that would

meet their needs. HI

_ I would wait for them to approach me about the matter. VI

- It's my duty to take care of them; I would insist they live with me. VC

14. You have your own job with a steady income, and you finally have enough for a place of your own. What do you think your parents will say when you tell them that you're moving out?

_ My family would be disappointed. HC 
_ My parents would be proud and impressed. HI

- My parents would not approve of this unless I were getting married. VC

- My parents would not be overly impressed because they had always assumed I would be able to take care of myself. VI

15. Imagine you are the parent of a teen-age child: Your teenage child comes to you and says s/he's found a really good part-time job and wants to know if it's okay to accept it. What would you say?

_ Sure, a job will teach you independence and responsibility. HI

- Go ahead, it's about time you started contributing to the family income! VI

- No, you're still a child and your obligations to help around the house and do schoolwork come first. VC

_ What do you need a job for? Don't I provide for you well enough? HC

16. It's a Saturday afternoon and you have nothing to do, so you think of visiting a friend. How would your friend react to this?

_ They won't mind if you show up without warning HC

_ You should at least call ahead and let them know you're on your way. HI

- It would be rude of you not to ask if it was all right beforehand. VC

- You should have given your friend a few day's notice that you wanted to get together. VI 


\section{APPENDIX B. FAMILY AND INDIVIDUAL CAUSES OF DEPRESSION SCALE}

Scoring and administration notes. Produces 4 sub-scales using items denoted by $\mathrm{C}$ (Family control), O (Family obligation), P (Personal achievement), S (Social achievement). Total possible score for each sub-scale is 30 (the 6 items in each times maximum rating of 5 for each).

For each item below rate how important you think it is forcausing depression specifically in yourself, and for people in general.Rate on a 5-point scale, from 1 meaning not at all a strong cause of depression, to 5, a very strong cause of depression. Use a rating of 2,3 or 4 to indicate that the item is a weak cause, medium cause or fairly strong cause of depression. If the item mentions children and you do not have children, imagine yourself at a future time when you may be a father or mother.

C Family disapproves of your friends

P Not satisfied with appearance

S Not as successful as friends are

C Parents want to control whatever you do

$P$ Can't achieve any desired goals

O Want children but do not have

S Rejected by boyfriend/girlfriend

O Lack of money makes it difficult to meet obligations to family

P Lack of money means can't pursue goals

O Can't give children things they deserve

S Don't make as much money as friends

O Don't take care of family well enough

C Parents compare you to your friends

P Don't have enough opportunities to have fun

$\mathrm{S}$ Too few friends or wrong friends

S Boyfriend/girlfriend too demanding or restrictive

O Don't spend enough time with parents

C Parents always trying to change you

$P$ Failed to do well at school/job

O Parents expression dissatisfaction with your performance

C Family doesn't give you enough freedom

C Family disapproves of your boyfriend/girlfriend

P Don't like school/job

S Can't attract boyfriend/girlfriend

$1-5$ rating

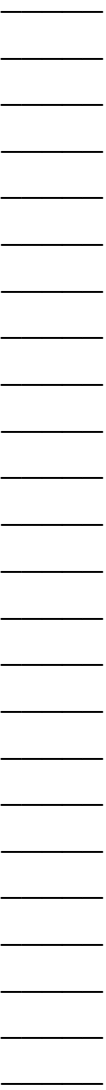

